\title{
Modeling Variation in Range Calf Growth under Condi- tions of Environmental Uncertainty
}

\author{
L.W. VANTASSELL, R.K. HEITSCHMIDT, AND J.R. CONNER
}

\begin{abstract}
Functional relationships between calf weights and various managerial and environmental factors were developed using 19 years of performance data from 8 cow-calf herds at the Texas Experimental Ranch. Six models were developed to estimate weights at (1) the first weighing at approximately 75 days of age, (2) the second weighing at approximately 152 days of age, (3) the second weighing, using the first weight as a dependent variable, (4) weaning at approximately 237 days of age, (5) weaning, using the first weight as a dependent variable, and (6) weaning, using the second weight as a dependent variable. $R^{2}$ values for the equations were $.79, .83, .90, .84, .89$, and .89 , respectively. Equations were functions of the graxing treatment (heavy continuous vs. moderate continuous vs. rotational grazing), level of winter supplementation, age of calf at weighing, crossbreeding, linear and quadratic accumulated production year precipitation, and winter/spring temperatures. Performance of the equations was examined by stochastically simulating them for 360 iterations using 36 years of historical precipitation.
\end{abstract}

Key words: rangeland, cow-calf, grazing management, weight gains

An increasing awareness of the impact of risk and uncertainty on range improvement decisions has been manifest throughout the agricultural literature over the past several years (e.g., Whitson et al. 1982, Spielman et al. 1985, Karp and Pope 1984). To incorporate risk into an applied decision analysis, a determination of the variability inherent in the basic variables and parameters, and how the variability relates to the system as a whole must be made. Many times the major limitation to risk modeling is the lack of suitable data to develop these relationships.

Annual variation in ranch income can be attributed to fluctuations in levels of inputs and outputs and the instability of their corresponding prices. Accurate representation of range livestock production levels necessitates a coalition with environmental conditions if uncertainty in production levels is to be addressed. While considerable research has examined the effects of various factors on cattle production (Smoliak 1956, Sneva and Hyder 1962, Sneva 1977, Clayton et al. 1983), a complete linkage from climatic conditions and managerial considerations to livestock production is often missing. For example, livestock production data may be available for a study area but if a continuous series of vegetation data and climatic conditions is not available, the link between environment and livestock performance is assumedly negated.

The objective of this study was to examine the relationships between climatic conditions, managerial factors, and calf performance at various time intervals between birth and weaning. While a whole science of genetics exists that enables researchers to develop sophisticated biological growth models for livestock (c.g., Sanders and Cartwright 1979), our aim was to develop models simplified enough to be easily incorporated into an economic analysis. The objective was not necessarily to predict calf weights, but to represent the variability existing within the system.

\footnotetext{
Authors are research associate, Department of Agricultural Economics, Texas A\&M University, College Station; associate professor, Texas Agricultural Experiment Station, Vernon; and professor. Department of Agricultural Economics, Texas A\&M University, College Station. The senior author is currently at the Department of Agricultural Economics and Rural Sociology, Univ. of Tennessee, Knoxville 37901-1071.

Report is published with approval of the Director, Texas Agricultural Experiment Station, as TA No. 22117.

Manuscript accepted 19 November 1986.
}

\section{Methods}

\section{Study Area}

Data for this study were collected at the Texas Experimental Ranch located in the eastern portion of the Rolling Plains of Texas. The ranch consists of 2,900 ha of native range. Principal range sites are clay loam, clay flat, loamy bottomland, and rocky hills. Vegetation is a mixture of mid and shortgrasses. Dominant herbaceous species are sideoats grama [Bouteloua curtipendula (Michx.) Torr.], a warm-season midgrass, buffalograss [Buchloe dactyloides (Nutt.) Engelm.], a warm-season shortgrass, and Texas wintergrass (Stipa leucotricha Trin. and Rupr.), a coolseason midgrass.

Climate is highly variable, consisting of warm, wet springs and falls, hot summers, and mild winters. Average annual precipitation is $682 \mathrm{~mm}$. During the period from 1960 through 1984, mean annual precipitation ranged from $491 \mathrm{~mm}$ in 1970 to $849 \mathrm{~mm}$ in 1969. Average monthly temperatures ranged from a low of $4^{\circ} \mathrm{C}$ in January to a high of $29^{\circ} \mathrm{C}$ in July. For a more complete description of the study area see Heitschmidt et al. (1985).

\section{Data Set}

Cow-calf production data from 4 grazing treatments were utilized in this study. The 4 treatments were: yearlong continuous grazing stocked at heavy (HC) and moderate (MC) rates; 4pasture, 3-herd deferred rotation (DR) stocked at a moderate rate; and 16-paddock, 1-herd rotation (RG) stocked at a very heavy rate. Stocking rates in all treatments were periodically adjusted to maintain relatively constant levels of grazing pressure. The data set from the $\mathrm{HC}, \mathrm{MC}$, and DR treatments spanned the 25 -year period from 1960 through 1985. Average rates of stocking during the 25 years were 5.1, 7.1, and $6.8 \mathrm{ha} / \mathrm{cow} /$ year, respectively. The RG treatment was initiated in 1981. Average rate of stocking in the RG treatment during the 5 years of study was $3.9 \mathrm{ha} / \mathrm{cow} /$ year.

Two herds of Hereford cows bred to Hereford bulls were utilized for the period 1960 through 1978. From 1979 through 1985, data were attained from Hereford $X$ Angus cows bred to Charlois bulls. To be considered valid test animals, replacement cows and their calves had to be in their respective treatment for a minimum of 1 year. This restriction prevented the use of the 1960,1969, 1975, and 1979 data in this study. Data from 1976 through 1978 were excluded because the supplemental feeding regime and calving seasons during these years differed significantly from the other periods.

Levels of protein supplement fed during winters varied among years and treatments. From 1960 through $1974,0.68 \mathrm{~kg} / \mathrm{cow} /$ day of cottonseed cake ( $41 \%$ crude protein) was fed 3 times per week for approximately 90 days. From 1960 through 1968, 1 of the 2 herds in both the HC and MC treatments and all 3 herds in the DR treatment were fed. From 1970 through 1974, 1 herd in each of the 3 treatments was fed. From 1980 through 1985, the level of supplement ( $20 \%$ crude protein range cubes) was varied depending on the grazing treatment and year. However, level of supplement fed within a year was essentially equal in the 2 heavily stocked treatments ( $\mathrm{HC}$ and $\mathrm{RG}$ ) and likewise in the 2 moderately stocked treatments (MC and DR).

All cows and calves were weighed periodically during each production year with an average weight obtained for the calves from each herd. Calf weights utilized in this study were the March-April weight when the calves were about 75 days old, June weight when 
Table 1. Descriptive statistics of calf weights (kg) at the Texas Experimental ranch for the periods of 1960-1974 and 1980-1985.

\begin{tabular}{|c|c|c|c|c|c|c|}
\hline \multirow[b]{2}{*}{ Years } & \multirow[b]{2}{*}{ Weigh dates 1} & \multirow{2}{*}{$\begin{array}{l}\text { Average age at } \\
\text { weighing (days) }\end{array}$} & \multirow[b]{2}{*}{ Average weight } & \multirow[b]{2}{*}{ Standard deviation } & \multicolumn{2}{|c|}{ Range } \\
\hline & & & & & Low & High \\
\hline $1961-1974$ & $\begin{array}{c}\text { 1st } \\
\text { 2nd } \\
\text { Weaning }\end{array}$ & $\begin{array}{r}76 \\
158 \\
239\end{array}$ & $\begin{array}{r}91 \\
163 \\
219\end{array}$ & $\begin{array}{l}12.2 \\
15.3 \\
18.0\end{array}$ & $\begin{array}{r}57 \\
120 \\
165\end{array}$ & $\begin{array}{l}121 \\
198 \\
264\end{array}$ \\
\hline $1980-1985$ & $\begin{array}{c}\text { 1st } \\
\text { 2nd } \\
\text { Weaning }\end{array}$ & $\begin{array}{r}75 \\
146 \\
234\end{array}$ & $\begin{array}{l}106 \\
184 \\
261\end{array}$ & $\begin{array}{l}11.3 \\
24.1 \\
20.6\end{array}$ & $\begin{array}{r}82 \\
140 \\
223\end{array}$ & $\begin{array}{l}128 \\
235 \\
307\end{array}$ \\
\hline
\end{tabular}

11 st weighing occurred in March/April; 2nd weighing occurred in June; 3rd weighing (weaning) occurred in late August/early October.

the calves were approximately 152 days old, and weaning weight when the calves were around 237 days old (Table 1). For a more complete description of these data sets see Heitschmidt et al. (1982).

\section{Model Development}

Previous work at the ranch indicated calf weights varied as a function of calf age, level of winter supplement fed the cow herd, and grazing treatment (Kothmann et al. 1970, Heitschmidt et al. 1982). Thus age of the calf (days) and level of winter supplement fed (Table 2) were incorporated into the model directly as independent variables. Because earlier analyses of these data showed no

Table 2. Winter supplemental feeding regime based as total crude protein fed per cow.

\begin{tabular}{lll}
\hline \hline Years & Herds fed & $\begin{array}{l}\text { Total crude protein' } \\
(\mathrm{kg} / \text { cow/year })\end{array}$ \\
\hline $1961-1968$ & A,B,K,L,M & 25.1 \\
$1970-1974$ & A,B,K & 25.1 \\
1980 & A,F,B,K,M & 16.3 \\
1981 & A,F,S & 24.5 \\
& B,D,K,L,M & 16.3 \\
1982 & A,F,S & 24.0 \\
1983 & D,K,M & 16.0 \\
1984 & A,F,S & 13.3 \\
1985 & A,F,S & 25.8 \\
& A,B,D,F,K,L,M,S & $72.1,42.1,30.9,78.9$, \\
& & $30.1,28.4,34.0,74.8$, \\
& & respectively \\
\hline
\end{tabular}

'Grazing treatment herds are: $A \& F=$ heavy continuous, $B \& D=$ moderate continuous; $K, L$, and $M=$ deferred rotation; $S=$ rotational grazed.

${ }_{2}^{2}$ Total crude protein $=\%$ crude protein * rate of feed * number of days fed.

significant effect of grazing treatment when stocked at a moderate rate (MC vs. DR) after adjusting for differences in age of calves (Heitschmidt et al. 1982), grazing treatments were limited to differences in rate of stocking (MR \{MC and DR\} vs. HC vs. RG). Bivariate dummy variables were utilized to distinquish between grazing treatments and also between straightbred and crossbred calves.

Availability and quality of forage, as affected by environmental growing conditions, is a major source of variability in range cattle production. Because a continuous series of forage standing crop estimates were not available, a direct link between climatic conditions and animal performance was adopted.' The independent

\footnotetext{
1 Before weaning calves basically receive their nourishment from maternal milk production and intake of range forage. Maternal milk production could enter the model as (1) a condition score on the cow or (2) the actual cow weight (or change in weight between weighing periods). Since cow condition scores were not available, an attempt was made to model cow weights. Because of the low explanatory ability $\left(R^{2}<.45\right)$ of the cow weight models (using basically the same independent variables as proposed for the calf weight models), excessive variation was exhibited in the predicted cow weights which was further pronounced in the estimated calf weights. We therefore opted to exclude cow weights as independent variables, believing milk production was indirectly accounted for in the models by inclusion of elimatic variables and kevel of winter supplement fed the cow herd.
}

climatic variables utilized in this study were various combinations of accumulated monthly precipitation $(\mathrm{cm})$ and aggregated average minimum monthly temperatures $\left({ }^{\circ} \mathrm{C}\right.$ )(Sneva 1977 , Clayton et al. 1983). Precipitation data were collected on the ranch, while the temperature data were obtained from Throckmorton (NOAA 1985), located about $10 \mathrm{~km}$ south of the ranch.

Plots of calf weights vs. climatic variables indicated that calf weights increased at a decreasing rate with respect to the amount of precipitation received. Various model specifications (log, quadratic, and linear) for the climatic variables were therefore examined. Calculated $t$-statistics indicated coefficients for several precipitation variables were significant $(P<0.05)$ for the linear and quadratic specifications. Because of greater $R^{2}$ values and ability to more accurately replicate the original data under simulated trials, a quadratic specification for precipitation was included in the models. Various specifications were also examined for the temperature variables, but the calculated $t$-statistics indicated only a linear specification was significant $(P<0.10)$. Several precipitation variables composed of various accumulated monthly totals were examined in each equation to identify the best combination for predicting each weight. Temperature variables were chosen using stepwise regression procedures via the maximum $R^{2}$ improvement technique (Fruend and Minton 1979).

\section{Results and Discussion}

The data set extended itself to development of 6 equations (Table 3) relating calf weights at first, second, and third weighings to the aforementioned independent variables. Based on these equations several biologically meaningful scenarios can be forwarded. Weights in early spring (equation 1) were positively related to age of calf, precipitation from the previous August to March (Prec), minimum temperatures during calving in January and February (Temp), level of winter supplement (Suppl), and crossbreeding (CB). Rate of stocking (HC and RG) and precipitation squared (Prec Sq) were negatively related to weights in early spring. We hypothesize the relationship to August through March precipitation reflected the effect of moisture during this period on forage production and in turn its effect on cow performance and ultimately calf weight. The negative relationship with the quadratic precipitation variable was a reflection that calf weights increased at a decreasing rate with respect to precipitation. The effect of reduced forage standing crop during fall and winter on cow-calf performance presumably induced the negative relationship of calf weights to stocking rates.

Similar relationships were apparent in explaining calf weights at the second (WT2) and third (WT3) weighings in equations 2 and 4. Positive factors were age of calf, accumulated rainfall from the previous August to weighing (Prec), late winter and spring temperatures (Temp), crossbreeding (CB), and level of winter supplement (Suppl). Negative factors were quadratic precipitation variables (Prec Sq) and rate of stocking (HC and RG). While the potential exists, because of the quadratic term, for additional precipitation to decrease calf weights, this occurs outside the range of precipita- 
Table 3. Regression coefficients for various variables predicting calf weights at various times during year.

\begin{tabular}{|c|c|c|c|c|c|c|}
\hline \multirow[b]{2}{*}{ Variable ${ }^{2}$} & \multirow{2}{*}{$\begin{array}{l}\text { Wt at first weighing } \\
\text { (WT1) } \\
\text { Equation } 1\end{array}$} & \multicolumn{2}{|c|}{$\begin{array}{l}\text { Wt at second weighing } \\
\text { (WT2) }\end{array}$} & \multicolumn{3}{|c|}{$\begin{array}{l}\text { Wt at weaning } \\
\text { (WT3) }\end{array}$} \\
\hline & & Equation 2 & Equation 3 & Equation 4 & Equation 5 & Equation 6 \\
\hline Intercep & $\begin{array}{l}-7.36 \\
(0.76)^{1}\end{array}$ & $\begin{array}{l}-76.18 \\
(5.21)^{* * *}\end{array}$ & $\begin{array}{l}-63.42 \\
(5.52)^{* * * *}\end{array}$ & $\begin{array}{l}-88.49 \\
(2.74) * * *\end{array}$ & $\begin{array}{l}-66.21 \\
(2.68)^{* * *}\end{array}$ & $\begin{array}{r}-11.10 \\
(0.47)\end{array}$ \\
\hline WT1 & & & $\begin{array}{c}1.11 \\
(18.61)^{* * *}\end{array}$ & & $\begin{array}{l}0.81 \\
(9.80)^{* * *}\end{array}$ & \\
\hline WT2 & & & & & & $\begin{array}{c}0.65 \\
(10.73)^{* * *}\end{array}$ \\
\hline Days & $\begin{array}{l}0.72 \\
(13.58)^{* * * *}\end{array}$ & $\begin{array}{c}0.89 \\
(12.80)^{* * *}\end{array}$ & $\begin{array}{c}0.70 \\
(11.76)^{* * *}\end{array}$ & $\begin{array}{l}0.64 \\
(9.62)^{* * *}\end{array}$ & $\begin{array}{l}0.51 \\
(11.01)^{* * * *}\end{array}$ & $\begin{array}{l}0.49 \\
(8.67)^{* * * *}\end{array}$ \\
\hline Suppl & $\begin{array}{l}0.20 \\
(4.70) * * *\end{array}$ & $\begin{array}{l}0.26 \\
(4.20)^{* * *}\end{array}$ & $\begin{array}{r}0.07 \\
(1.48)\end{array}$ & $\begin{array}{l}0.18 \\
(2.28)^{* *}\end{array}$ & $\begin{array}{l}0.11 \\
(1.55)\end{array}$ & $\begin{array}{c}0.08 \\
(1.11)\end{array}$ \\
\hline $\mathrm{HC}$ & $\begin{array}{l}-6.87 \\
(5.45)^{* * * *}\end{array}$ & $\begin{array}{l}-9.01 \\
(5.07)^{* * * *}\end{array}$ & $\begin{array}{l}-1.78 \\
(1.23)\end{array}$ & $\begin{array}{l}-9.58 \\
(4.29)^{* * *}\end{array}$ & $\begin{array}{l}-4.58 \\
(2.30)^{* *}\end{array}$ & $\begin{array}{l}-4.13 \\
(2.08)^{* *}\end{array}$ \\
\hline RG & $\begin{array}{l}-11.48 \\
(3.28)^{* * *}\end{array}$ & $\begin{array}{l}-21.00 \\
(4.22)^{* * *}\end{array}$ & $\begin{array}{l}-9.32 \\
(2.38)^{* *}\end{array}$ & $\begin{array}{l}-22.91 \\
(3.68)^{* * *}\end{array}$ & $\begin{array}{l}-15.02 \\
(2.81)^{* * *}\end{array}$ & $\begin{array}{l}-10.02 \\
(1.80)^{*}\end{array}$ \\
\hline $\mathrm{CB}$ & $\begin{array}{l}15.81 \\
(12.90)^{* * *}\end{array}$ & $\begin{array}{l}37.16 \\
(19.86)^{* * *}\end{array}$ & $\begin{array}{l}17.36 \\
(10.69)^{* * *}\end{array}$ & $\begin{array}{l}51.53 \\
(21.84)^{* * *}\end{array}$ & $\begin{array}{l}39.42 \\
(16.19)^{* * *}\end{array}$ & $\begin{array}{l}28.45 \\
(9.84)^{* * *}\end{array}$ \\
\hline Prec & $\begin{array}{l}1.87 \\
(5.86)^{* * *}\end{array}$ & $\begin{array}{l}2.71 \\
(6.99)^{* * * *}\end{array}$ & $\begin{array}{l}3.46 \\
(6.90)^{* * *}\end{array}$ & $\begin{array}{l}3.05 \\
(3.99)^{* * *}\end{array}$ & $\begin{array}{l}4.43 \\
(4.29)^{* * * *}\end{array}$ & $\begin{array}{l}2.63 \\
(2.51)^{* *}\end{array}$ \\
\hline Prec Sq & $\begin{array}{l}-0.016 \\
(4.92)^{* * *}\end{array}$ & $\begin{array}{l}-0.019 \\
(6.42)^{* * *}\end{array}$ & $\begin{array}{l}-0.048 \\
(7.49)^{* * *}\end{array}$ & $\begin{array}{l}-0.020 \\
(3.97)^{* * *}\end{array}$ & $\begin{array}{l}-0.05 \\
(4.59)^{* * *}\end{array}$ & $\begin{array}{l}-0.031 \\
(2.53)^{* *}\end{array}$ \\
\hline Temp & $\begin{array}{c}1.08 \\
(3.35)^{* * * *}\end{array}$ & $\begin{array}{c}0.47 \\
(1.76)^{*}\end{array}$ & $\begin{array}{c}0.71 \\
(3.29)^{* * *}\end{array}$ & $\begin{array}{l}1.44 \\
(4.42)^{* * *}\end{array}$ & $\begin{array}{l}1.46 \\
(5.35)^{* * *}\end{array}$ & $\begin{array}{c}1.03 \\
(3.44)^{* * * *}\end{array}$ \\
\hline$R^{2}$ & .79 & .83 & .90 & .84 & .89 & .89 \\
\hline Std Dev & 6.43 & 9.06 & 6.92 & 11.43 & 9.46 & 9.51 \\
\hline
\end{tabular}

$*, * *, * * *$ Significant at the $0.10,0.05$, and 0.01 levels, respectively.

'Numbers in parentheses are absolute values of calculated $t$-satistics.

${ }^{2}$ Days $=$ Age of calf at first weighing for Equation 1

$=$ Age of calf at second weighing for Equation 2,

$=$ Days between first and second weighing for Equation 3

$=$ Age of calf at weaning for Equation 4,

$=$ Days between first and third weighing for Equation 5 .

$=$ Days between second and third weighing for Equation 6 ,

Suppl = Total crude protein supplemented during winter.

$\mathrm{HC}$ = Yearlong continuous grazing at heavy rate of stocking ( 1 if $\mathrm{HC}$, otherwise 0 ).

RG = Rotational grazing ( 1 if RG, otherwise 0 ).

CB = Breed effect ( 1 if crossbred, 0 otherwise).

Prec = Accumulated precipitation,

= August in the previous year to March in the current year for Equation 1.

$=$ August in the previous year to June in the current year for Equation 2,

$=$ December in the previous year to June in the current year for Equation 3,

$=$ August in the previous year to August in the current year for Equation 4,

$=$ February to August in the current year for Equation 5 and 6 .

Prec Sq = same as Prec but value is squared

Temp = Sum of average minimum monthly temperatures,

= January to February in the current year for Equation 1,

= January to April in the current year for Equation 2 and 3,

$=$ January to May in the current year for Equations 4, 5 , and 6.

tion experienced in the Throckmorton area during the past 36 years.

When WT1 was included as an independent variable for predicting WT 2 and WT3 (equations 3 and 5), supplementation was no longer significant $(P<0.10)$. This indicated the inclusion of supplementation in equations 2 and 4 was primarily related to its direct effect on WT1 and its indirect effect on WT2 and WT3. The insignificance $(P>0.10)$ of HC on WT2 when WT1 was included as an explanatory variable, indicated reduced gain from heavy continuous grazing was not pronounced between the 2 weighings.

\section{Model Validation}

Performance of the calf weight models was examined via Monte Carlo simulation. Climatic data obtained from Throckmorton (NOAA 1985) from 1950 through 1985 was replicated 10 times to obtain 360 climatic observations for use in the simulation. From this, 360 calf weights were stochastically obtained for each of the 6 equations using the relationship

$$
\tilde{Y}_{i j}=Y_{i j}+S_{i} * R_{j} \text { for } i=1,2, \ldots, 6 \text { and } j=1,2, \ldots, 360
$$

where $\tilde{Y}_{i j}$ is the simulated calf weight from the $i^{\text {th }}$ equation for the $j^{\text {th }}$ iteration, $Y_{i j}$ is the estimated calf weight from the $i^{\text {th }}$ equation using the $\mathrm{j}^{\text {th }}$ precipitation and temperature observation, $S_{i}$ is the standard deviation of the $i^{\text {th }}$ equation, and $R$ is the $j^{\text {th }}$ random normal deviate $\left(\mu=0 ; \sigma^{2}=1\right)$ obtained from a random normal deviate generator. It was assumed the RG and HC cow herds were supplemented at 25 units of total crude protein while the MR herd was not supplemented. Calf ages of 75,146 , and 234 days were assumed for the first, second, and third weighing, respectively.

Descriptive statistics are contained in Table 4 for the simulated equation results. For comparison purposes, the actual statistics for each grazing strategy for 1980 through 1985 are presented along with indexed weight statistics for the MR and $\mathrm{HC}$ herds. Indexed weight statistics were obtained by dividing the 1961 through 1974 and 1980 through 1985 data by the mean of their respective periods. This created 2 indices with 1.0 being the average weight for both periods. Indexed values were then multiplied by the 1980 
Table 4. Selected statistics for the actual 1980-1985 weights (kg), indexed 1961-1985 weights and stochastically simulated equations using precipitation and temperature data from 1950-1985.'

\begin{tabular}{|c|c|c|c|c|c|c|c|c|c|c|c|c|}
\hline & \multicolumn{3}{|c|}{ First weighing } & \multicolumn{4}{|c|}{ Second weighing } & \multicolumn{5}{|c|}{ Weighing Weights } \\
\hline & Actual & Indexed & Equation 1 & Actual & Indexed & Equation & 2 Equation 3 & Actual & Indexed & Equation & 4 Equation & 5 Equation 6 \\
\hline \multicolumn{13}{|c|}{$\begin{array}{l}\text { Moderate } \\
\text { Stocked }\end{array}$} \\
\hline $\begin{array}{l}\text { Ave }^{2} \\
\text { Sid }\end{array}$ & 101 & 104 & $103^{* *}$ & 178 & 178 & 184 & $180^{*}$ & 259 & 255 & 263 & 259 & $260^{*}$ \\
\hline Std & 13 & 15 & $10^{* * *}$ & 20 & 19 & $13^{* * *}$ & $20^{* * *}$ & 15 & 19 & $14^{* * *}$ & $23^{* *}$ & $19^{* *}$ \\
\hline Min & 82 & 66 & 75 & 149 & 136 & 149 & 125 & 232 & 197 & 215 & 197 & 204 \\
\hline $\operatorname{Max}$ & 128 & 136 & 124 & 211 & 211 & 212 & 222 & 281 & 281 & 297 & 313 & 305 \\
\hline \multirow{2}{*}{\multicolumn{13}{|c|}{$\begin{array}{l}\text { Heavy } \\
\text { Continuous }\end{array}$}} \\
\hline & & & & & & & & & & & & \\
\hline Ave & 103 & 102 & $101^{* *}$ & 181 & 180 & $181^{* * *}$ & 178 & 258 & 255 & $258 *$ & $255^{* *}$ & $257^{*}$ \\
\hline Std & 6 & 9 & $10^{* *}$ & 18 & 15 & $13^{* * *}$ & 20 & 20 & 19 & $14^{* * * *}$ & $23^{* * *}$ & $19^{* * *}$ \\
\hline Min & 95 & 85 & 73 & 163 & 157 & 146 & 123 & 233 & 216 & 209 & 194 & 200 \\
\hline $\operatorname{Max}$ & 114 & 118 & 122 & 215 & 215 & 210 & 220 & 283 & 283 & 292 & 309 & 302 \\
\hline \multirow{2}{*}{\multicolumn{13}{|c|}{$\begin{array}{l}\text { Rotational } \\
\text { Grazing }\end{array}$}} \\
\hline & 97 & - & 96 & 159 & - & 170 & & 242 & - & 244 & $241^{*}$ & $242^{*}$ \\
\hline $\begin{array}{l}\text { Ave } \\
\text { Std }\end{array}$ & 8 & - & 10 & 14 & - & $13^{* * *}$ & 20 & 14 & - & $14^{* * *}$ & 23 & 19 \\
\hline Min & 91 & - & 69 & 140 & - & 134 & 110 & 223 & - & 196 & 180 & 186 \\
\hline $\operatorname{Max}$ & 109 & - & 118 & 172 & - & 197 & 207 & 255 & - & 279 & 295 & 288 \\
\hline
\end{tabular}

1***. and *** indicate no statistical significance $(P<0.05)$ between the simulated mean or standard deviation and the actual, indexed, or both actual and indexed, respectively. ${ }^{2} \mathrm{Ave}=$ average, Std $=$ standard deviation; $\operatorname{Min}=\operatorname{minimum} ; \operatorname{Max}=\operatorname{maximum}$

through 1985 average to provide an extended crossbred data set. While crossbred weights may not vary in the same manner as straightbred, indexing hopefully provides an indication of the variation in weight over this period.

Statistical significance of the difference between the empirical and simulated means was tested by comparing a calculated $t$ statistic with tabular values at the $95 \%$ significance level. A Chi Square $\left(\chi^{2}\right)$ statistic was also computed and compared with the appropriate tabular value $(P<0.05)$ to test the difference between each set of standard deviations (Clements et al. 1971). The difference observed between each set of means for MR and HC was significant in 2 equations for $M R$ and 1 equation for $H C$. The differences between simulated and empirical standard deviations were only significant in equation 3 for HC. For the RG strategy, several of the differences between each set of means and standard deviations were significant. While the model's ability to replicate the RG strategy may be questioned with only 4 data points available to draw information from, the simulated data may be representative of the variation occurring within the RG system over this larger range of climatic conditions.

The simulated data extended beyond the range observed in the empirical data in each equation except for the MR strategy in equation 1. It is noteworthy that for most $\mathrm{HC}$ and $\mathrm{MR}$ equations, less than 5\% of the 360 data points fell outside the range given by the empirical data. Exceptional cases of protrusion were for equations 5 and $6(\mathrm{MR})$ and equations 3 and $5(\mathrm{HC})$, where $17 \%, 13 \%$, $18 \%$, and $15 \%$ of the observations extended outside the range, respectively. For the RG system a relatively large number of simulated points were found outside the observed range. The largest percent of outliers was $52 \%$ for equations 3 and 5 , with the fewest being $27 \%$ for equation 4 . The outlying data points may in part be explained by the increased weather observations and assumptions made about management practices. Using an average supplementation rate and calf age removed the flexibility to vary date of weaning or alter the level of supplementation under fluctuating environmental conditions, thus creating weights beyond those normally obtained.

Cumulative probability distributions from equation 4 are presented in Figs. 1, 2, and 3 for each of the grazing strategies. The cumulative probability distributions were developed for the actual, indexed, and simulated data sets by sorting each data set from lowest to highest and accumulating the probabilities of occurrence for each observation. A slightly higher probability existed for

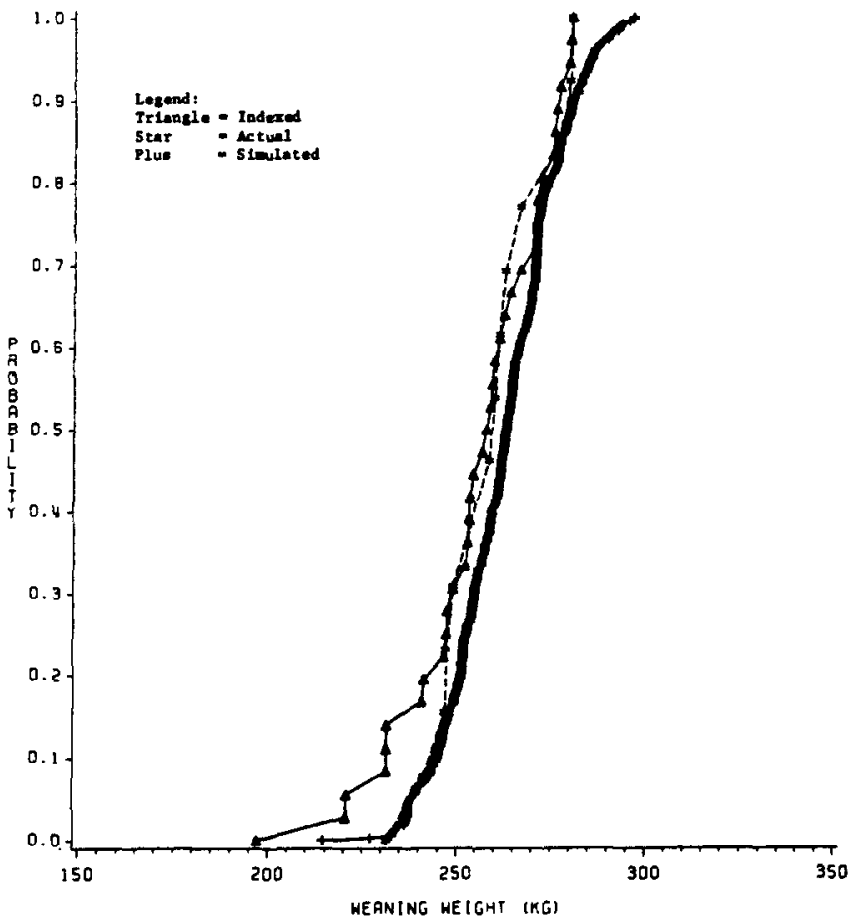

Fig. 1. Cumulative probability distributions for the simulated (Equation 4), actual, and indexed moderate stocked grazing strategy.

heavier weights under the simulated MR distribution than for the actual or indexed distributions. The simulated RG distribution exhibited a slightly higher probability of lower weights below 240 $\mathrm{kg}$ but a higher probability of heavier weights above $245 \mathrm{~kg}$ than did the actual distribution. All actual and indexed distributions were relatively steep at the upper tail while the simulated distributions tailed off more slowly. Perhaps more accuracy could be obtained in simulation by placing a ceiling on the maximum weight and stacking all protruding weights at the ceiling. 


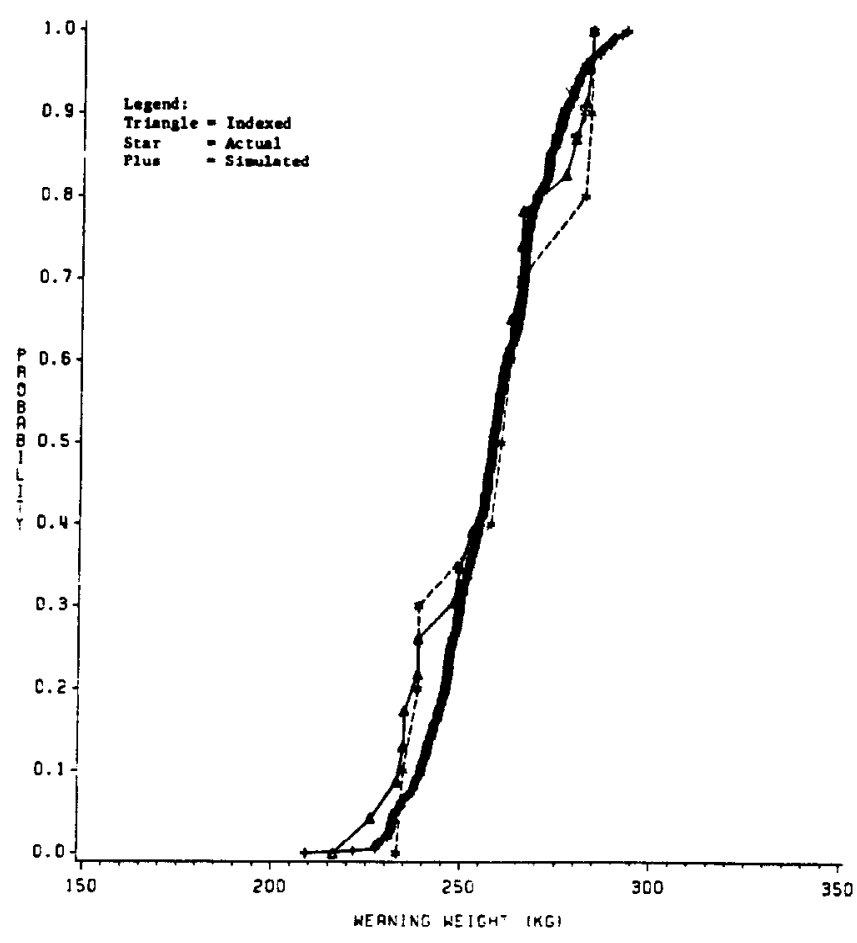

Fig. 2. Cumulative probability distributions for the simulated (Equation 4), actual, and indexed heavy continuous grazing strategy.

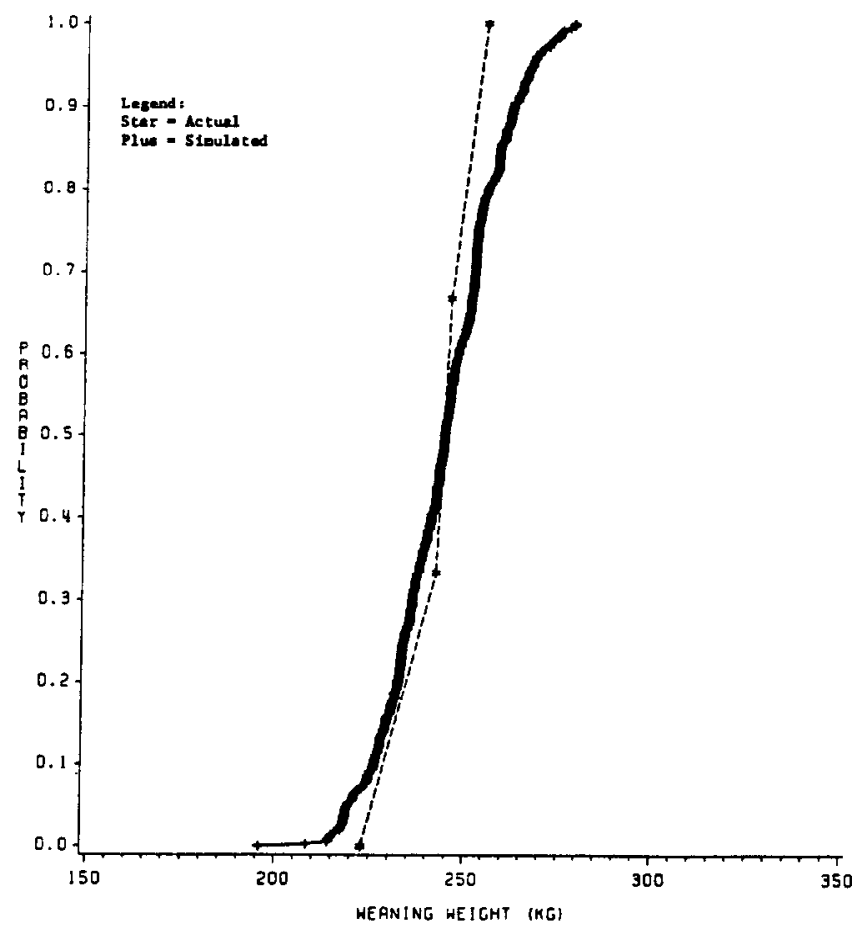

Fig. 3. Cumulative probability distributions for the simulated (Equation 4) and actual rotational grazing strategy.

\section{Conclusions}

This study attempted to relate annual variations in calf weights in the Rolling Plains of Texas to various managerial, biological, and meteorological variables. Average weight of calves during branding and vaccination (WTI) is apparently dependent upon the condition of the cows during gestation and lacation, as well as the climatic stress placed upon both the cow and the young calf. These factors were partially accounted for in the model by inclusion of the accumulated previous August through March precipitation and the combincd average minimum temperature during calving in January and February. Rate of stocking and level of winter supplement were also important factors, as was calf age. Average calf weights during June and at weaning (models 2 through 6 ) were related to a combination of variables including calf age, environmental growing conditions as accounted for by accumulated precipitation during the production year and winter/spring temperatures, level of winter supplement, crossbreeding, and stocking rate.

The utility of this study is related not only to its biological interpretation, but also in its ability to enhance an economic analysis. The ability to mathematically explain biological and environmental relationships is very useful in economic analyses, especially when the uncertainty involved in the production of an output is inbedded within those relationships. The weigh dates examined in this study are at strategic decision-making times for ranchers in the Rolling Plains of Texas (Riechers 1986). Marketing decisions such as forward contracting could be better examined and the assessment of future cash flow requirements facilitated with a reliable representation of weaning weights. Decisions as to postponing or shortening the weaning date or providing supplemental feed for expected lighter weaning calves could also be enhanced. The models also have the possibility of providing a distribution of expected weights when considering a new breeding program for a ranch which has little historical data on weaning weights. Lastly, the models provide a format for examining the profitability and risk inherent between moderately stocked, heavy continuous, and short duration grazing strategies.

\section{Literature Cited}

Clements, A.M., H.P. Mapp, and V.R. Eidman. 1971. A procedure for correlating events in farm firm simulation models. Oklahoma State Univ. Tech. Bull. T-131.

Clayton, L.H., R.P. Morris, and J.R. Wight. 1983. Using precipitation to predict range herbage production in Southwestern Idaho. J. Range Manage. 36:766-770.

Fruend, R.J., and P.D. Minton. 1979. Regression methods: A tool for data analysis. Marcel Dekker Inc. New York.

Heitschmidt, R.K., M.M. Kothmann, and W.J. Rawlins. 1982. Cow-calf response to stocking rates, grazing systems, and winter supplementation at the Texas Experimental Ranch. J. Range Manage. 35:204-210.

Heitschmidt, R.K., S.L. Dowhower, D.L. Price, and R.A. Gordon. 1985. Response of vegetation to livestock grazing at the Texas Experimental Ranch. Texas Agr. Exp. Sta. Bull. 1515.

Karp, L., and A. Pope. III. 1984. Range management under uncertainty. Amer. J. Agr. Econ. 66:437-446.

Kothmann, M.M., G.W. Mathis, P.T. Marion, and W.J. Waldrip. 1970. Livestock production and economic returns from grazing treatments at the Texas Experimental Ranch. Texas Agr. Exp. Sta. Bull. 1100.

National Oceanic and Atmospheric Administration. 1985. Climatological data-Texas. Vol. 90. USDC.

Riechers, R.K. 1986. An economic analysis of alternative stocking rate adjustment strategies for short duration grazing systems in the Texas Rolling Plains. M.S. Thesis. Texas A\&M Univ. College Station.

Sanders, J.O., and T.C. Certwright. 1979. A general cattle production systems model I. Structure of the model. Agr. Systems. 4:217.

Smoliak, S. 1956. Influence of climatic conditions on forage production of shortgrass rangeland. J. Range Manage. 9:89-91.

Sneva, F.A. 1977. Correlation of precipitation and temperature with spring, regrowth, and mature crested wheatgrass yields. J. Range Manage. $30: 270-275$.

Sneva, F.A., and D.N. Hyder. 1962. Estimating herbage production on semiarid ranges in the intermountain region. J. Range Manage. 15:88-93.

Spielman, K.A., T.R. Harris, and R.L. Shane. 1985. Selecting a crested wheatgrass seeding range improvement: An application of generalized stochastic dominance. Annu. Meeting Amer. Agr. Econ. Ass, selected paper. Amer. J. Agr. Econ. 67:1271.

Whitson, R.E., R.K. Heitschmidt, M.M. Kothmann, and G.K. Lundgren. 1982. The impact of grazing systems on the magnitude and stability of ranch income in the Rolling Plains of Texas. J. Range Manage. 35:526-532. 